\title{
Upaya Pengembangan Softskill Pengelola Keuangan pada Kelompok Usaha Rahmatan lil'alamin Bandar, Batang
}

\author{
Jilma Dewi Ayu Ningtyas*1, Ardiyan Darutama², Ulfa Kurniasih³
}

\author{
1,2,3Program Studi Akuntansi Syariah, Fakultas Ekonomi dan Bisnis Islam, IAIN Pekalongan, Indonesia

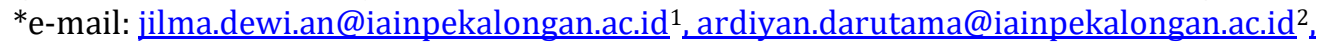 \\ ulfakurniasih@gmail.com ${ }^{3}$
}

\begin{abstract}
Abstrak
KU Rahmatan Lil'alamin ingin mengembangkan usaha jual beli tapi terkendala pengetahuan yang minim mengenai bagaimana mengelola asset dan pencatatanya serta pengelompokannya sesuai dengan peraturan. Mengetahui asset atau harta terlebih dahulu merupakan salah satu cara untuk mendukung strategi berbisnis apa yang akan dikembangkan, apalagi disaat pandemic covid-19 sangat memberi dampak negative terhadap banyak sector di Indonesia (Marasabessy, 2021). Kendala ini akan mempengaruhi terwujudnya visi dan misi dari KU Rahmatan Lil'alamin apabila tidak segera diselesaikan. Berdasarkan uraian latar belakang di atas, maka kegiatan pengabdian ini dilaksanakan melalui pendampingan dengan edukasi dan pelatihan internal organisasi. Tujuan utama membantu mengelola, mencatat dan mengelompokkan asset Kelompok Usaha Rahmatan lil'alamin, Bandar berdasarkan jenis-jenis harta yang disesuaikan dengan peraturan Menteri keuangan no. 96/PMK.03/2009. Kegiatan dilakukan dengan menggunakan metode pendampingan terhadap pengelola keuangan. hal ini diharapkan pengelola mampu dan memahami bagaimana mengelola, mencatat dan mengelompokkan asset yang dimiliki oleh Kelompok Usaha Rahmatan lil'alamin, Bandar. Kegiatan dilaksanakan selama 3 hari yaitu hari pertama persiapan, hari kedua pengenalan materi dan praktikum dengan menggunakan laptop. Dan hari ketiga evaluasi pelaksanaan kegiatan. Berdasarkan hasil evaluasi kegiatan dapat disimpulkan bahwa setelah mendapatkan pelatihan mengenai pengelolaan, pencatatan dan pengelompokan asset berdasarkan peraturan Menteri keuangan no. 96/PMK.03/2009, pengelola Kelompok Usaha Rahmatan lil'alamin, Bandar terjadi peningkatan pemahaman mengenai bagaimana mengelola asset, mencatat asset dan mengelompokkan asset yang sesuai dengan peraturan.
\end{abstract}

Kata kunci: Pencatatan Aset, Softskill Pengelola Keuangan

\begin{abstract}
KU Rahmatan Lil'alamin wants to business develop but is constrained by minimal knowledge about how to manage assets and their records and group them according to regulations. Knowing assets or assets in advance is one way to support what business strategies will be developed, especially when the COVID-19 pandemic has had a very negative impact on many sectors in Indonesia (Marasabessy, 2021). This obstacle will affect the realization of the vision and mission of KU Rahmatan Lil'alamin if it is not resolved immediately. Based on the description of the background above, this service activity is carried out through assistance with education and internal training of the organization. The main objective is to manage, record, and classify the assets of the Rahmatan lil'alamin, Bandar Business Group based on the types of assets in accordance with the regulation of the Minister of Finance no. 96/PMK.03/2009. Activities are carried out using the method of mentoring financial managers. It is hoped that the manager will be able and understand how to manage, record and classify assets owned by the Rahmatan lil'alamin Business Group, Bandar. The activity was carried out for 3 days, namely the first day of preparation, the second day of material introduction and practicum using a laptop. And the third day of evaluation of the implementation of activities. Based on the results of the activity evaluation, it can be concluded that after receiving training on the management, recording and grouping of assets based on the regulation of the Minister of Finance no. 96/PMK.03/2009, manager of the Rahmatan lil'alamin Business Group, Bandar there is an increase in understanding on how to manage assets, record assets and classify assets in accordance with regulations.
\end{abstract}

Keywords: Asset Recording, Financial Management Softskill 


\section{PENDAHULUAN}

Islam merupakan agama Rohmatan lil'alamin, membuat hidup manusia tenang, damai, tentram, dan sejahtera. Islam memiliki aturan yang menyangkut segala aspek kehiduapan manusia, salah satunya peraturan mengenai kegiatan manusia dalam memenuhi kebutuhannya guna mencapai kesejahteraan lahir dan batin yang disebut ekonomi islam (Hidayatullah, 2020). Lahirnya sistem ekonomi islam didasarkan pada pemikiran agama tidak hanya memberikan aturan soal kebutuhan iman tapi dapat menjawab persoalan yang dihadapi manusia termasuk ekonomi. (Budiantoro, 2018) Manusia membutuhkan penghidupan yang lebih baik untuk bertahan sehingga diperlukan usaha yang seiring dengan kemampuan dan kecerdasan dalam menghadapi masalahnya (Efendi, 2018). Peran ekonomi islam dalam perekonomian sangat memilki pengaruh cukup besar sehingga ekonomi islam perlu diterapkan dan ditingkatkan untuk membantu masyarakat yang terlilit hutang (Mardoni Y, 2021). Ekonomi Syariah sebagai suatu pemikiran ekonomi saat ini berkembang sangat pesat (Ansori, 2016).

Kelompok Usaha Rahmatan Lil 'alamin berdiri pada tahun 2016, didirikan oleh 18 orang pendiri yang sebagian besarnya adalah anggota Komunitas Badar. Pendirian Kelompok Usaha Rahmatan Lil 'alamin dilatarbelakangi oleh keprihatinan kondisi masyarakat yang memiliki potensi untuk berkembang namun tidak ada wadah yang mengakomodir sehingga banyak yang terjerat praktik riba oleh para rentenir. Selain daripada hal tersebut para pendiri menginginkan praktik perekonomian yang berazazkan syariah baik dalam penyimpanan, pembiayaan, maupun kerjasama lainnya di masa yang akan datang demi perkembangan kelompok usaha. Ekonomi Syariah merupakan ekonomi rakyat berkeadilan, bukan mengaktualkan ekonmi konglomerat seperti halnya ekonomi kapitalis yang berorientasi profit semata (Hidayatullah, 2020) Kelompok Usaha ini bergerak di bidang simpan pinjam dan jual beli barang milik anggota. Secara sederhana pinjaman dapat diartikan sebagai barang atau jasa yang menjadi kewajiban pihak yang satu untuk dibayarkan kepada pihak lain sesuai dengan perjanjian tertulis atau lisan dengan jangka waktu pengembalian yang telah disepakati (Musdalipah, 2021). Simpan pinjam yang dijalankan Kelompok Usaha (KU) Rahmatan Lil'alamin tanpa riba seperti yang dijelaskan di Al-Qur'an QS. An-Nissa' : 160 -161 yang artinya "Maka disebabkan kezaliman orang-orang Yahudi, Kami haramkan atas (memakan makanan) yang baik-baik (yang dahulunya) Dihalalkan bagi mereka, dan karena mereka banyak menghalangi (manusia) dari jalan Allah. Dan disebabkan mereka memakan riba, Padahal Sesungguhnya mereka telah dilarang daripadanya, dan karena mereka memakan harta benda orang dengan jalan yang batil. Kami telah menyediakan untuk orang-orang yang kafir di antara mereka itu siksa yang pedih." Oleh sebab itu KU Rahmatan Lil'alamin sangat berkomitmen di bidang simpan pinjam ini.

Berdasarkan survey di lapangan pencatatan asset dan pengelolaanya belum maksimal. KU Rahmatan Lil'alamin ingin mengembangkan usaha jual beli tapi terkendala pengetahuan yang minim mengenai bagaimana mengelola asset dan pencatatanya serta pengelompokannya sesuai dengan peraturan Menteri keuangan no. 96/PMK.03/2009. Mengetahui asset atau harta terlebih dahulu merupakan salah satu cara untuk mendukung strategi berbisnis apa yang akan dikembangkan, apalagi disaat pandemic covid-19 sangat memberi dampak negative terhadap banyak sector di Indonesia (Marasabessy, 2021). Kendala ini akan mempengaruhi terwujudnya visi dan misi dari KU Rahmatan Lil'alamin apabila tidak segera diselesaikan. Berdasarkan uraian latar belakang di atas, maka kegiatan pengabdian ini dilaksanakan melalui pendampingan dengan edukasi dan pelatihan internal organisasi dengan Upaya pengembangan softskill Pengelola Keuangan atas pencatatan Aset pada Kelompok Usaha Rahmatan lil'alamin Bandar, Batang.

\section{METODE}

Kegiatan ini dilaksanakan di kantor sekretariat Kelompok Usaha Rahmatan lil'alamin Bandar, Batang. Kegiatan dilaksanakan selama 3 hari dengan pendampingan pada bulan November 2021. Adapun bentuk pelaksanaan kegiatan ini terdapat tiga tahapan yaitu: 


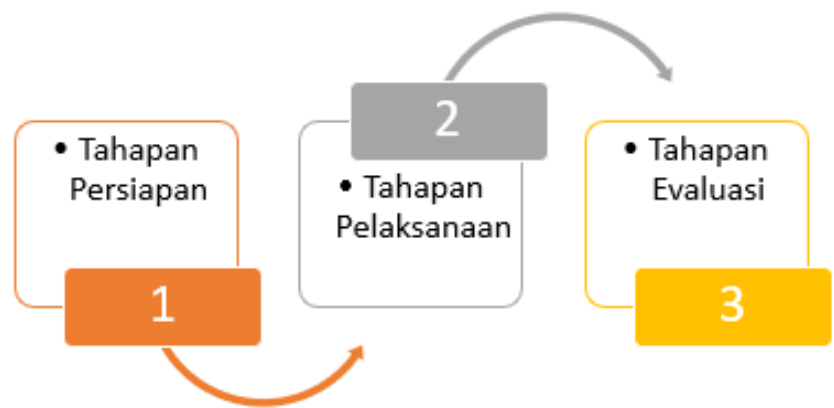

Gambar 1. Tahapan Kegiatan PKM

Tahapan-tahapan kegiatan dapat dijabarkan sebagai berikut:

1. Tahapan Persiapan

Pada tahap ini tim mengidentifikasi permasalahan yang dilamai oleh mitra selanjutnya permasalahan tersebut di carikan solusinya yaitu dengan membuat materi mengenai pengelolaan, pencatatan dan pengelompokan asset yang dimiliki oleh Kelompok Usaha Rahmatan lil'alamin Bandar, Batang. Pada tahap ini tim melaksanakan koordinasi terkait bagaimana pelaksanaannya nanti

2. Tahapan Pelaksanaan

Pendampingan dan pelatihan pengelolaan, pencatatan dan pengelompokan asset dilaksanakan di kantor sekretariat Kelompok Usaha Rahmatan lil'alamin Bandar, Batang. Pelatihan diberikan berupa materi tentang asset kemudian dilanjutkan praktik pengelompokkan asset dan pencatatnya sampai dengan bagaimana menyusutkan asset serta diskusi dan tanya jawab.

3. Tahapan Evaluasi

Evaluasi dilakukan secara langsung pada akhir pertemuan. Evaluasi ini dilakukan untuk melihat tingkat pemahaman dari pengelola keuangan di Kelompok Usaha Rahmatan lil'alamin Bandar, Batang mengenai bagaimana pengelolaan, pencatatan, pengelompokkan asset berdasarkan jenis-jenis harta yang disesuaikan dengan peraturan Menteri keuangan no. 96/PMK.03/2009.

\section{HASIL DAN PEMBAHASAN}

Pelaksanaan Pendampingan dan pelatihan tentang pengelolaan, pencatatan, pengelompokkan asset berdasarkan jenis-jenis harta yang disesuaikan dengan peraturan Menteri keuangan no. 96/PMK.03/2009, diawali dengan pelaksanaan pretest yang berisi pertanyaan dasar mengenai asset. Soal pretest dibagikan kepada peserta pelatihan untuk dapat dikerjakan terlebih dahulu sebelum narasumber memberikan materinya. Jawaban soal pretest berupa persentase pengetahuan peserta tentang pengelolaan asset, pencatatan asset, pengelompokan asset, perolehan asset dan penyusutan asset. Hasil evaluasi jawaban soal pretest rata-rata peserta dari 5 pertanyaaan tentang pengetahuan dasar asset nilainya $32 \%$. Berikut Gambar 2 adalah pengerjaan Pretestnya.

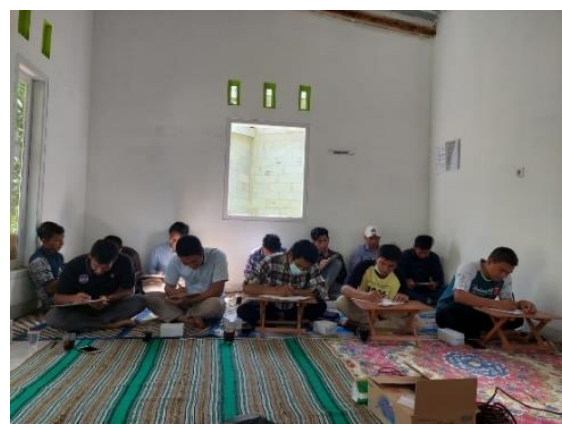

Gambar 2. Kegiatan Pengerjaan Test 
Kegiatan selanjutnya adalah penjelasan tentang pengertian Aset, Aset UMKM, Klasifikasi Aset, pengelompokan asset, perhitungan harga perolehan asset dan penyusutan asset. Aset merupakan harta yang dimiliki oleh UMKM saat ini dan memiliki manfaat ekonomi dimasa depan yang diharapkan UMKM. (IAI, 2018). Masa manfaat ekonmi dimasa depan maksudnya adalah potensi asset tersebut memberikan kontrbusi baik secara langsung maupun tidak langsung pada arus kas UMKM.Arus kas UMKM bisa timbul dari penggunaan maupun pelepasan asset. Asset memiliki biaya yang dapat diukur dengan handal. Aset UMKM diklasifikasikan menjadi Aset Lancar dan Aset tetap. Aset lancar diperkirakan akan direalisasi atau dimiliki untuk dijual atau dihunakan dalam jangka waktu operasionalnormal UMKM, asset lancar juga berupasemua yang dimiliki untuk diperdagangkan dan diharapkan akan direalisasikan dalam jangka waktu 12 bulan. Misalnya Kas, Deposito berjangka dan piutang.

Aset tetap dimiliki UMKM untuk digunakan dalam kegiatan operasional yang diharapkan dapat dgunakan lebih dari 1 periode atau 1 tahun operasional UMKM. Contoh aset tetap seperti tanah, bagunan, kendaraan, aset biologis seperti hewan dan tumbungan dapat diakui sebagai aset tetap tetapi untuk aset biologis apabila siap untuk dipanen maka akan diakui sebagai persediaan dan bukan lagi aset tetap. Aset tetap dicatat sebesar biaya perolehannya yaitu harga beli + biaya-biaya lainnya untuk mendapatkan aset tersebut sampai kepada UMKM. Untuk penyusutan aset merut SAK EMKM menggunakan perhitungan dengan metode garis lurus dan metode saldo menurun. Untuk metode garis lurus digunakan untuk menghitung penyusutan aset dimana dalam bagiannya sama besar, selama masa manfaat yang sudah ditetapkan terhadap aset tersebut. Sedangkan metode saldo menurun digunakan untuk menghitung penyusutan pada bagian yang menurun yaitu dengan cara menerapkan tarif penyusutan atas sisia buku pada akhir masa manfaat yang disusutkan sekaligus. Masa manfaat dan tarif harta penyusutan fiscal berdasarkan Undang-undang No, 36 tahun 2008 dapat dlihat pada Tabel 1 dibawah ini

Table 1. Tarif Penyusutan Aset

\begin{tabular}{llll}
\hline $\begin{array}{l}\text { Kelompok Harta } \\
\text { Berwujud }\end{array}$ & Masa Manfaat & $\begin{array}{l}\text { Tarif penyusutan } \\
\text { metode garis lurus }\end{array}$ & $\begin{array}{l}\text { Tarif penyusutan } \\
\text { metode saldo menurun }\end{array}$ \\
\hline Bukan Bangunan & 4 Tahun & $25 \%$ & \\
Kelompok I & 8 Tahun & $12,5 \%$ & $50 \%$ \\
Kelompok II & 16 Tahun & $6,25 \%$ & $25 \%$ \\
Kelompok III & 20 Tahun & $5 \%$ & $12,5 \%$ \\
Kelompok IV & & \\
$\begin{array}{l}\text { Bangunan } \\
\text { Permanen }\end{array}$ & 20 Tahun & & \\
Tidak Permanen & 10 Tahun & & \\
\hline
\end{tabular}

Sumber: Undang-undang No. 36, 2008

Pada Pemaparan materi diselingi dengan tanya jawab dan diskusi mengenai kasus yang terjadi di KU rahmatan lil'alamin. Kami juga menawarkan beberapa solusi dan memberikan tambahan pengetahuan. Ada beberapa pertanya dari peserta mengenai pengelompokkan asset, serta bagaimana aset bisa berhubungan dengan strategi bisnis yang akan dilakukan kedepannya dan menurut beberapa peserta, pada realitanya dilapangan asset UMKM masih bercampur dengan Aset Pribadi sehingga untuk pembukuan, pencatatannya belum maksimal. Berikut Gambar 3 adalah pemaparan materi oleh narasumber.

Setelah kegiatan diskusi dan tanya jawab selesai kami memberikan tes Kembali yaitu postest dengan pertanyaan yang sama di tes sebelumnya. Pada hasil evaluasi tes terakhir didapatkan bahwa nilai rata-ratanya naik 24\% menjadi 56\% yang dapat dilihat pada Gambar 4.

Setelah diberikan bimbingan dan arahan serta diskusi didapat kesimpulan bahwa pengelola KU rahmatan lil'alamin perlu memiliki pembukuan tersendiri untuk asset usahanya selain usaha simpan pinjam yang memang menjadi pionir simpan pinjam tanpa riba. Kemudian untuk strategi usaha yang akan dijalankan perlu dilakukan analisis kelayakan usaha terlebih dahulu. 


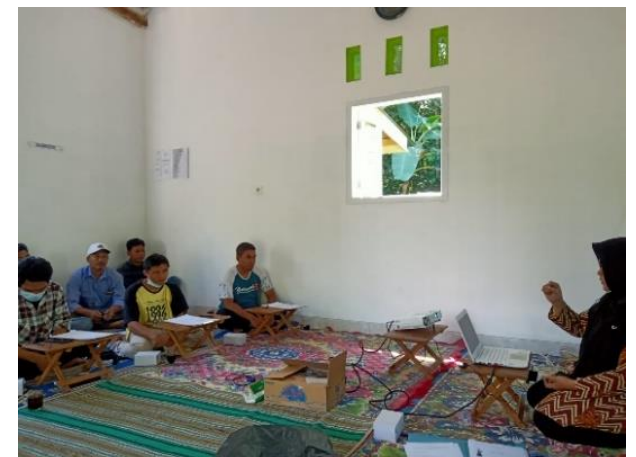

Gambar 3. Dokumentasi Pemberian Materi dari Narasumber

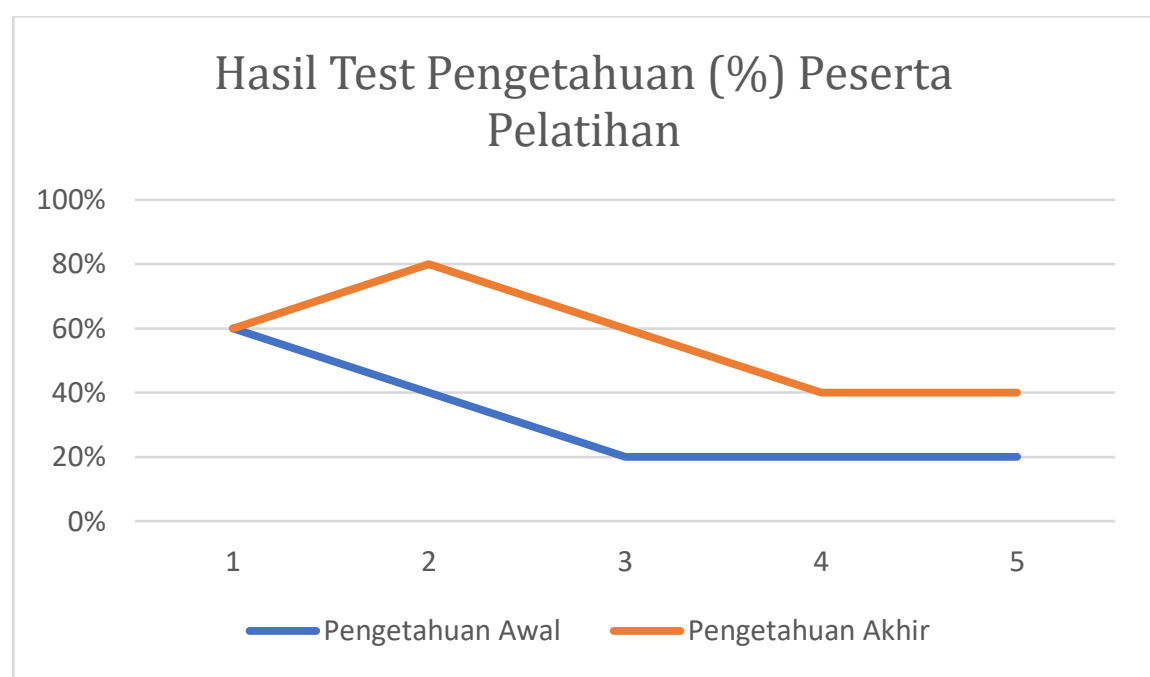

Gambar 4. Hasil Evaluasi Pengetahuan Peserta

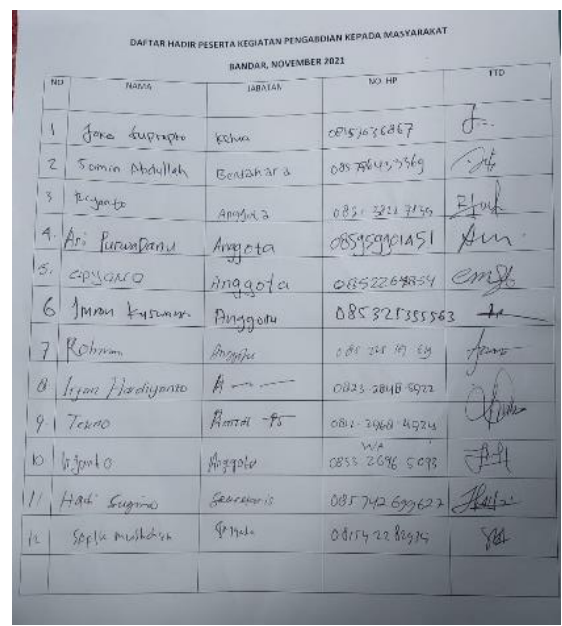

Gambar 5. Daftar Hadir Peserta

\section{KESIMPULAN}

Kesimpulan dari pelaksanaan pengabdian kepada masyarakat mengenai upaya pengembangan softskill Pengelola Keuangan atas pencatatan Aset pada Kelompok Usaha Rahmatan lil'alamin Bandar, Batang. Dilaksanakan dengan 3 tahapan yaitu tahapan persiapan, tahapan pelaksanaan dan tahapan evaluasi. Tahapan persiapan tim mengidentifikasi permasalahan yang dilamai oleh mitra selanjutnya permasalahan tersebut di carikan solusinya. Tahapan selanjutnya adalah tahapan pelaksanaan yaitu pelatihan diberikan berupa materi 
tentang asset kemudian dilanjutkan praktik pengelompokkan asset dan pencatatnya sampai dengan bagaimana menyusutkan asset serta diskusi dan tanya jawab, dimana pengelolaan, pencatatan, pengelompokkan asset berdasarkan jenis-jenis harta yang disesuaikan dengan peraturan Menteri keuangan no. 96/PMK.03/2009 dapat dilaksanakan dengan lancar. Tahapan ketiga adalah evaluasi yang dilakukan secara langsung pada akhir pertemuan. Evaluasi ini dilakukan untuk melihat tingkat pemahaman dari pengelola keuangan di Kelompok Usaha Rahmatan lil'alamin Bandar, Batang mengenai bagaimana pengelolaan, pencatatan, pengelompokkan asset,

Dari hasil evaluasi pengetahuan dan pemahaman peserta didapatkan hasil bahwa pengetahuan dan pemahaman mengalami peningkatan sebesar $24 \%$. Pengelola KU rahmatan lil'alamin perlu memiliki pembukuan tersendiri untuk asset usahanya selain usaha simpan pinjam yang memang menjadi pionir simpan pinjam tanpa riba. Kemudian untuk strategi usaha yang akan dijalankan perlu dilakukan analisis kelayakan usaha terlebih dahulu untuk meminimalisir kerugian dan perlu membuat NPWP badan tersendiri atas nama KU Rahmatan lil'alamin yang tidak bercampur dengan pribadi anggota atau pengelola keuangannya

Pada akhir kegiatan pelatihan dan pendampingan, Kelompok Usaha Rahmatan lil'alamin Bandar mengucapkan terimakasih telah dipilih menjadi mitra dalam kegiatan pengabdian kepada masyarakat yang diadakan oleh Fakultas Ekonomi dan Bisnis Islam IAIN Pekalongan. Ketua Kelompok Usaha Rahmatan lil'alamin Bandar menyampaikan juga untuk kedepannya masih dijadikan mitra lagi karena masih banyak yang belum diketahui. Beliau juga berharap untuk dapat diadakan pendampingan dan pelatihan serupa dengan tema yang berbeda misalnya masalah perpajakan seperti pendampingan pengisian e-spt perorangan dan e-spt badan.

\section{UCAPAN TERIMA KASIH}

Penulis mengucapkan terima kasih kepada Fakultas Ekonomi dan Bisnis Islm IAIN Pekalongan yang telah memberi dukungan financial terhadap pengabdian ini. Harapan dari kegiatan ini dapat memberikan manfaat bagi Pengelola Keuangan Kelompok Usaha Rahmatan lil'alamin Bandar khususnya dan bagi Para pembaca pada umumnya.

\section{DAFTAR PUSTAKA}

Ansori, A. (2016). Digitalisasi Ekonomi Syariah. Jurnal Ekonomi Keuangan dan Bisnis Islam Volume 7 No.1, 1-18.

Budiantoro, d. (2018). Sistem Ekonomi (Islam) dan Pelarangan Riba dalam Perspektif Historis. Jurnal Ilmiah Ekonomi Islam, 1-13.

Efendi, R. (2018). Konsep Koperasi Bung Hatta dalam Perspektif Ekonomi Syariah. Jurnal AlHikmah Vol.15 No.1 April, 111-135.

Hidayatullah, M. S. (2020). Membumikan Ekonomi Syariah di Indonesia. Jurnal Hukum dan Ekonomi Islam , 177-207.

IAI. (2018). Standar Akuntasi Keuangan Entitas Mikro Kecil Menengah. Jakarta: IAI.

Marasabessy, A. I. (2021). Entrepreneurship: Membangun Bisnis di Masa Pandemi Covid-19. Jurnal Bisnis \& Kewirausahaan, 151-157.

Mardoni Y, H. M. (2021). Pengelolaan BUMDES Cikahuripan Maju Berbasis Ekonomi Syariah. Jurnal Pengabdian Kepada Masyarakat, 68-74.

Musdalipah, d. (2021). FORMULASI KONSEP KELOMPOK SIMPAN PINJAM KHUSUS PEREMPUAN PROGRAM NASIONAL PEMBERDAYAAN MASYARAKAT MANDIRI PEDESAAN (PNPM-MP) DALAM PERSPEKTIF EKONOMI SYARIAH. Jurnal Lembaga Keuangan,Ekonomi dan Bisnis Islam, 11-24. 